\title{
Perspectives on Whether or Not to Vote and on the Complexity of Democratic Elections
}

\author{
Richard J. Cebula ${ }^{1}$
}

Published online: 29 December 2016

(C) International Atlantic Economic Society 2016

\section{JEL D70 $\cdot$ E62}

Within the context of current political and economic realities, several perspectives on voting experiences, voter behavior and turnout, and the complexity of the election process are provided in this special section of the Atlantic Economic Journal. The first study by Hansen, Shughart, and Yonk examines the controversial 2015 Greek referendum. In particular, on July 5, 2015, Greek citizens voted on whether their country should accept the terms of austerity offered by the European Union (EU) for a bailout from the country's financial crisis. With an overall turnout rate of $62.5 \%, 61.3 \%$ of those voting voted "no." While a majority of voters in every district opposed the bailout's terms, the margin against the proposed austerity measures ranged from $51.2 \%$ in Lakonia to $73.8 \%$ in Chania. This study explores whether political parties influenced voters' decisions to accept or reject the EU's budgetary reforms. The study examines whether party platforms are merely "cheap talk" or are salient in determining electoral outcomes. Formal hypothesis testing is undertaken at the voting district level. The key independent variable is party influence, which is measured by party vote shares in the nationwide election held in January 2015. The dependent variable is the percentage that voted "no" to austerity on July 5, 2015 in each of Greece's 56 electoral districts. The model controls for average age and the unemployment rate across regions, as well as the fraction of firsttime voters in each electoral district. Empirical estimation implies that a pro-austerity party (New Democracy) was a significant factor impacting the results of the referendum. This research finding bolsters the claim that political parties can shape electoral outcomes on questions decided via direct democracy.

A substantial literature finds an interaction between economic and political institutions, suggesting that more market-oriented economic institutions tend to enhance the durability of

Richard J. Cebula

rcebula@ju.edu; dr.richardcebula@gmail.com

1 Davis College of Business, Jacksonville University, Jacksonville, FL 32211, USA 
democratic political institutions. The empirical analysis in the Boudreaux and Holcombe study supports this hypothesis. Measuring economic institutions using the Fraser Institute's Economic Freedom of the World Index, when democratic governments are established in countries ranking in the top quarter of that index, $90 \%$ of them remain democratic after 20 years. For countries in the bottom $20 \%$, the establishment of democratic governments has a $50 \%$ chance of reverting to autocracy within four years and only a $10 \%$ chance of remaining democratic after 20 years. The empirical results strongly support Friedman's conjecture that market institutions enhance the viability of democratic governments.

The study by Cebula et al. focuses upon the 2000, 2004, 2008, and 2012 general elections and the fact that the latter two elections were characterized by a minority major political party candidate for President. The hypothesis being investigated is that in the absence of a minority candidate for major political office, minority voter participation rates reflect voter apathy because the expected net benefits from voting are close to zero. However, if there is a minority candidate for a major political office, the expected net benefits from voting for minorities increase so that minority voter participation is greater. It was found that voter turnout among registered voters in a state was unaffected by the percentage of the state's population that was either African-American or Hispanic during the 2000 and 2004 election cycles. However, during the 2008 and 2012 election cycles, voter turnout among registered voters was positively and statistically significantly related to the state's percentage of its population that was either African-American or Hispanic.

Voter participation rates vary widely across the 50 states and the District of Columbia. An empirical study by Cebula et al. sought, within the context of a broadened version of the "rational voter model," to identify determinants of this geographic variation. Using the 2014 mid-term general election as the study period, it was found that voter turnout across states and the District of Columbia was positively related to whether there was a close governor's race, whether there was a close U.S. Senate race, the percentage of the population aged 65 and over, the number of referenda on the ballot, and the degree of voting by mail. In addition, voter turnout is negatively related to the percentage of the population that is either Hispanic or African-American.

There is a debate in the U.S. regarding the impact of swing or independent voters in American politics. While some argue that swing voters either do not swing or have only a marginal impact on election campaign outcomes, the decline in voter partisan identification and the rise of independents means that they arguably do have a potential impact on elections, making them an entity of interest to many candidates. Additionally, presidential elections represent a unique case for swing voters. A robust literature notes that during the presidential primary and caucus process, voters in states such as Iowa or New Hampshire effectively have a greater voice in the election than those in other states. This is due to the number of voters in these states, and the strategic importance of having their primaries and caucuses poised at the beginning of the presidential primary season. Furthermore, the Electoral College is criticized as giving disproportionate influence to some voters or states or otherwise distorting voter participation rates and the results in presidential elections because of a winner-take-all method of allocating votes in 48 out of the 50 states. Using these assertions as background, the question arises whether the impact or distortion that swing-voters have in some states compared to others, in terms of their relative influence on presidential elections, can be quantified. Related to this issue is whether the Electoral College actually distorts the impact of swing voters. The study by Duquette et al. 
assesses the impact of swing voters within this method that states use to allocate electoral votes. By looking at several recent U.S. presidential elections, how the winner-take-all method of allocating electoral votes produces disparities in the voting power of citizens across states is quantified.

The study by Hall and Pokharel contributes to the literature on the political economy of road funding and political economy models generally. Hall and Pokharel develop and then estimate a political economy model using 2013 data and find that the primary driver of state government highway expenditures is federal highway aid per mile. Hall and Pokharel fail to find evidence that railroad or trucking interests play a role in the determination of state highway spending. However, from a public policy standpoint, they suggest that other special interests might now be more powerful in determining state government road expenditures. The authors suggest that future research explore what these special interests might be as well as obtain more years of data in order to explore the dynamics of state road funding over a longer time frame. 